\title{
BATAS - BATAS KEWAJIBAN MENJAGA KERAHASIAAN NOTARIS DALAM KAITANNYA HAK INGKAR NOTARIS BERDASARKAN UNDANG-UNDANG TENTANG JABATAN NOTARIS
}

\author{
Prasetya Agung Laksana*) \\ *) Mahasiswa Program Magister Kenotariatan UNISSULA, Email: prasetyaagung4@ gmail.com
}

\begin{abstract}
ABSTRAK
Penulis dalam tulisan ini mngambil judul diatas karena ingin mengetahui batasan kewenangan Notaris dalam menjaga kerahasiaan dalam kaitannya dengan Hak Ingkar Notaris, bagaimana proses pemanggilan Notaris sebagai saksi dan adakah akibat hukum bagi notaris yang membuka rahasia jabatannya serta bagaimana perlindungan hukum bagi Notaris itu sendiri.

Metode yang digunakan dalam penelitian ini menggunakan metode penelitian hukum normatif, yaitu pengumpulan data yang dilakukan melalui pendekatan yuridis normatif, dimana dilakukan penelusuran terhadap permasalahan yang telah dirumuskan dengan mempelajari ketentuan perundang- undangan yang berkaitan dengan permasalahan yang dibahas.

Batas-batas kewenangan Notaris dalam menjaga kerahasiaan dalam kaitannya dengan hak ingkar yaitu seorang Notaris yang berkewajiban menjaga isi Akta dan segala sesuatu yang diperoleh guna pembuatan Aktanya dan hanya boleh membuka isi akta kepada para pihak yang berkepentingan, ahli waris, atau orang yang dikehendaki para pihak diperbolehkan untuk mengetahui isi Akta tersebut.

Prosedur pemanggilan Notaris harus berdasarkan persetujuan Majelis Kehormatan Notaris dan Notaris harus menggunakan hak ingkarnya sebagai cara untuk menjaga kerahasiaan akta yang dibuatnya.

Akibat hukum seorang Notaris membuka isi akta tanpa persetujuan para pihak dapat dituntut baik secara pidana maupun perdata dan/atau sangsi yang diberikan Majelis Kehormatan Notaris. Notaris mendapat perlindungan hukum ketika membuka isi akta apabila notaris tersebut telah mendapat persetujauan dari para pihak yang berkepentingan.

Kata Kunci : Notaris, Hak Ingkar, Perlindungan Hukum Notaris
\end{abstract}

\section{1) PENDAHULUAN}

Profesi notaris sebagai suatu keahlian tentu baru bisa dilaksanakan kalau yang bersangkutan melalui pendidikan kekhususan, bahkan pelaksanaan tugas notaris merupakan pelaksanaan tugas jabatan yang esoteric, yaitu suatu profesi yang memerlukan pendidikan khusus dan kemampuan yang memadai untuk menjalankannya ${ }^{1}$. Di Indonesia sendiri profesi notaris sangat dipengaruhi

${ }^{1}$ Habib Adjie. (2009). Sanksi Perdata dan Administratif Terhadap Notaris sebagai Pejabat Publik. Bandung: Refika Aditama 


\section{JURNAL AKTA}

oleh tradisi sistem civil law. Dalam tradisi tersebut, profesi notaris termasuk pejabat umum yang diberikan delegasi kewenangan untuk membuat akta-akta yang isinya mempunyai kekuatan bukti formal dan berdaya eksekusi. Jenis notariat demikian disebut notaris fungsional (notariat functionnel). Notaris profesional (notariat professionnel) dalam tradisi sistem common law, aktaaktanya tidak mempunyai kekuatan seperti disebutkan kendati organisasi profesi ini diatur oleh pemerintah $^{2}$.

Dalam pasal 4 tentang sumpah dan janji Notaris dan Pasal 16 ayat (1) huruf (f) Undang-Undang Jabatan Notaris mewajibkan Notaris untuk menjaga kerahasiaan segala sesuatu mengenai akta yang dibuatnya dan segala keterangan yang diperoleh guna pembuatan akta sesuai dengan sumpah janji jabatan kecuali undang-undang menentukan lain. Artinya notaris wajib merahasiakan isi akta, tidak hanya apa yang dicantumkan dalam akta-aktanya, akan tetapi juga semua yang diberitahukan atau disampaikan kepadanya dalam kedudukannya sebagai notaris, sekalipun itu tidak dicantumkan dalam akta-aktanya. Sebagai salah satu perangkat hukum, notaris mempunyai hak ingkar sebagai pejabat umum yang profesional, dengan harus memegang sumpah jabatannya untuk tidak memberitahukan isi aktanya, di sisi lain notaris harus berdiri pada kepentingan negara yang mengacu pada kepentingan publik guna terselesainya proses hukum dalam peradilan, sehingga menghasilkan suatu putusan yang adil, bermanfaat dan menjamin kepastian hukum. Pelanggaran terhadap kewajiban tersebut berdasarkan Pasal 16 ayat (11) Undang-Undang Jabatan Notaris, seorang Notaris dapat dikenai sanksi berupa teguran lisan sampai dengan pemberhentian dengan tidak hormat.

Munculnya problematika hukum antara kewajiban Notaris dalam menjaga kerahasiaan akta dan terdapat ketentuan peraturan perundang-undangan yang menggugurkan hak ingkar. Menjadi sebuah

\footnotetext{
${ }^{2}$ Sidharta. Moralitas Profesi Hukum, Suatu Tawaran Kerangka Berpikir. 2006. Bandung: Refika
} 
Vol. 3 No. 4 Desember $2016: 1$ - 8

dilema hukum yang membuat hak ingkar profesi Notaris dalam kewajiban menjaga kerahasiaan akta dipertanyakan.

\section{2) RUMUSAN MASALAH}

Berdasarkan latar belakang sebagaimana telah diuraikan diatas, maka permasalahan berkenaan dengan penelitian ini dapat dirumuskan sebagai berikut :

1. Bagaimanakah batas-batas kewenangan Notaris dalam menjaga kerahasiaan dalam kaitannya dengan hak ingkar Notaris berdasarkan Undang-Undang tentang jabatan Notaris?

2. Bagaimana prosedur pemanggilan Notaris sebagai saksi dan cara Notaris mempertahankan Hak Ingkarnya?

3. Apakah akibat hukum dan adakah perlindungan hukum terhadap Notaris yang membuka rahasia jabatan Notaris?

\section{3) PEMBAHASAN}

1) Batas-Batas Kewenangan Notaris Dalam Menjaga Kerahasiaan Dalam Kaitannya Dengan Hak Ingkar Notaris Berdasarkan Undang-Undang tentang Jabatan Notaris.

Dalam kedudukan notaris sebagai saksi (perkara perdata) notaris dapat meminta dibebaskan dari kewajiban untuk membuat kesaksian karena jabatannya menurut UU diwajibkan untuk merahasiakannya. Sesuai pasal 1909 ayat (3) KUHPerd. Dalam hal ini notaris mempunyai kewajiban ingkar bukan untuk kepentingan diri notaris tetapi untuk kepentingan para pihak yang telah mempercayakan pembuatan Akta kepada notaris.

Pasal 54 UU Jabatan Notaris berbunyi "Notaris hanya dapat memberikan, memperlihatkan atau memberitahukan isi akta, Grosse Akta, Salinan Akta dan Kutipan Akta kepada orang yang berkepentingan langsung kepada akta, ahli waris atau orang yang mempunyai hak, kecuali ditentukan lain oleh peraturan perundang-undangan." Dari pasal tersebut jelas sudah diperintahkan kepada notaris untuk tidak memberikan, memperlihatkan atau memberitahukan 
isi akta kecuali kepada yang berkepentingan langsung. Seperti saat pihak yang berkaitan dengan akta tersebut bersengketa dan terdapat pihak lain yang ingin mendapatkan berita kemudian menemui notaris yang membuat akta tersebut, maka notaris tersebut harus menggunakan Hak Ingkarnya demi menjaga kepentingan para penghadapnya.

Di dalam menentukan seberapa jauh jangkauan hak ingkar dari para notaris, harus bertitik tolak dari kewajiban bagi para notaris untuk tidak bicara mengenai isi akta-aktanya, dalam arti baik mengenai yang tercantum dalam akta-aktanya maupun mengenai yang diberitahukan atau disampaikan kepadanya dalam kedudukannya sebagai notaris, sekalipun dimuka pengadilan, kecuali hal-hal dimana terdapat kepentingan yang lebih tinggi atau dalam hal-hal dimana untuk itu notaris oleh sesuatu peraturan perundang-undangan yang berlaku membebaskannya secara tegas dari sumpah rahasia jabatannya.

\section{2) Prosedur Pemanggilan Notaris Sebagai Saksi Oleh Penyidik Berkaitan Dengan Akta} Yang Dibuat Dan Cara Mempertahankan Hak Ingkar Notaris.

Dalam Undang-Undang Nomor 2 tahun 2014 tentang Jabatan Notaris Pasal 66 UUJN mengenai pengambilan minuta akta dan pemanggilan Notaris yang menyatakan:

1) Untuk kepentingan proses peradilan, penyidik, penuntut umum, atau hakim dengan persetujuan majelis kehormatan Notaris berwenang:

a. Mengambil fotokopi minuta akta dan/atau surat-surat yang dilekatkan pada minuta akta atau Protokol Notaris dalam penyimpanan Notaris; dan

b. Memanggil Notaris untuk hadir dalam pemeriksaan yang berkaitan dengan akta yang dibuatnya atau Protokol Notaris yang berada dalam penyimpanan Notaris.

2) Pengambilan fotokopi minuta akta atau surat-surat sebagaimana dimaksud pada ayat (1) huruf a, dibuat berita acara penyerahan. 
Vol. 3 No. 4 Desember $2016: 1$ - 8

Hak Ingkar selain untuk melindungi Notaris juga melindungi kepentingan klien. Karena Notaris tidak boleh memberitahukan isi akta. Contoh: misalnya ditanya oleh wartawan, maka seorang Notaris tersebut tidak diperkenankan memberikan keterangan apapun mengenai akta ataupun keterangan yang diperoleh dala pembuatan akta. Namun, ketika dimuka pengadilan, wajib untuk membuka isi akta yang kita buat. Berbeda ketika Notaris dihadapan penyidik, Notaris dapat memilih apakah bersedia memberikan keterangan atau tidak dan disinilah hak ingkar digunakan. ${ }^{3}$

\section{3) Akibat Hukum Dan Perlindungan Terhadap Notaris Yang Membuka Rahasia Jabatan}

\section{Notaris}

\section{Akibat Hukum Pelanggaran Rahasia Jabatan Notaris}

\section{Ancaman Pidana}

Apabila seorang notaris membuka rahasia jabatan yang di telah dipercayakan padanya, maka kepadanya diancam dengan pidana berdasarkan Pasal 322 Kitab UndangUndang Hukum Pidana.

Dari penjelasan diatas dapat disimpulkan bahwa seorang notaris harus mempertahankan hak ingkarnya untuk menjaga kerahasiaan akta yang dibuatnya selama hal tersebut tidak berkaitan dengan para pihak yang berkepentingan atau karena undang undang menentukan lain seperti saat notaris diminta sebagai saksi dimuka pengadilan.

2. Ancaman Perdata

Apabila Notaris maupun karyawan notaris membocorkan isi Akta kepada orang lain yang tidak berkepentingan dan menimbulkan kerugian terhadap para pihak yang

\footnotetext{
${ }^{3}$ Sugiyanto, S.H Notaris \& PPAT MPD Kabupaten Pati, dari hasil wawancara tanggal 01 Maret 2017
} 


\section{JURNAL AKTA}

berkepentingan, maka notaris tersebut dapat digugat secara perdata berdasarkan Pasal 1365 Kitab Undang-Undang Hukum Perdata menyatakan bahwa tiap perbuatan melanggar hukum, yang membawa kerugian pada orang lain, mewajibkan orang yang karena salahnya menerbitkan kerugian itu, mengganti kerugian tersebut.

3. Sanksi menurut Undang-Undang Jabatan Notaris

Pelanggaran terhadap kewajiban menjaga kerahasiaan jabatan dapat mengakibatkan notaris dikenakan sanksi oleh Majelis Pengawas Notaris, hal ini sesuai dengan ketentuan Pasal 85 Undang-Undang Jabatan Notaris antara lain : teguran lisan, teguran tertulis, pemberhentian sementara, pemberhentian dengan hormat, pemberhentian dengan tidak hormat oleh Menteri atas usul Majelis Pengawas Pusat.

\section{Perlindungan Hukum Terhadap Notaris Yang Membuka Isi (Rahasia) Akta}

Perlindungan hukum terhadap Notaris ini bertujuan, agar hak dan kewenangan maupun kewajiban Notaris dalam menjalankan tugasnya sebagaimana diberikan oleh UUJN dan Kode Etik dilakukan berdasarkan ketentuan yang berlaku, baik itu berdasarkan hukum maupun berdasarkan moral dan etika profesi, demi terjaminnya perlindugan hukum dan kepastian hukum bagi profesi Notaris dan kepentingan umum.

Dengan demikian akan tercipta rasa tenang, tentram dan perlindungan hukum yang terjamin bagi Notaris dalam melaksanakan tugasnya sebagai Pejabat Umum. Notaris akan merasa terlindungi karena segala tindakan pemeriksaan dilaksanakan sesudah pemeriksaan dan penelitian secara cermat oleh Majelis Pengawas sebagaimana diatur dalam Pasal 66 UUJN, tetapi Majelis Pengawas tidak dapat memberikan perlindungan apapun kepada Notaris yang terbukti bersalah dalam menjalankan jabatan Notaris.

\section{KESIMPULAN}


Vol. 3 No. 4 Desember $2016: 1$ - 8

Berdasarkan analisa dan pembahasan yang telah dilakukan dalam bab sebelumnya, penulis memberikan kesimpulan sebagai berikut:

1. Sesuai Pasal 16 ayat (1) huruf (f) Undang - Undang Nomor 2 Tahun 2014 tentang jabatan Notaris. Notaris diwajibkan merahasiakan isi Akta yang dibuatnya, kecuali Undang Undang menentukan lain.

2. Seorang Notaris hanya diperbolehkan membuka isi Akta kepada para pihak yang berkepentingan, ahli waris, atau orang yang dikehendaki para pihak diperbolehkan untuk mengetahui isi Akta tersebut karena Notaris pada hakekatnya hanya mengkopilir kehendak para pihak penghadap sehingga wajib menjaga kerahasiaan akta untuk melindungi kepentingan para pihak.

3. Prosedur pemanggilan Notaris sebagai saksi sesuai Pasal 66 Undang-Undang Nomor 2 tahun 2014 tentang Jabatan Notaris, memanggil Notaris untuk kepentingan proses peradilan, penyidik, penuntut umum atau hakim dengan persetujuan Majelis Kehormatan Notaris.

4. Cara notaris menjaga kerahasiaan dan mempertahankan hak ingkarnya, yaitu: Notaris harus menggunakan hak ingkarnya untuk menolak menjadi demi melindungi dan merahasiakan isi Akta yang dibuat olehnya, apabila notaris tetap ditanya mengenai isi akta, notaris tersebut menunjukkan peraturan perundang-undangan yang mengharuskannya merahasiakan isi akta yang dibuatnya.

3. Akibat hukum pelanggaran rahasia jabatan Notaris yaitu: Ancaman pidana, ancaman perdata dan sanksi menurut Undang-Undang Jabatan Notaris dari teguran sampai diberhentikan tidak hormat.

4. Perlindungan hukum terhadap Notaris yang membuka isi akta yaitu Notaris yang membuka isi akta dengan persetujuan para pihak yang berkepentingan untuk menjaga kepercayaan 
masyarakat kepada profesi Notaris dan atau Notaris yang karena jabatannya diminta untuk menjelaskan isi Akta yang dibuatnya dimuka pengadilan, secara otomatis Notaris mendapat perlindungan hukum sebagai saksi dan terbebas dari segala tuntutan.

\section{DAFTAR PUSTAKA}

\section{A. BUKU}

Adjie, Habib. (2009). Sanksi Perdata dan Administratif Terhadap Notaris sebagai Pejabat Publik. Bandung: Refika Aditama

Sidharta. 2006, Moralitas Profesi Hukum, Suatu Tawaran Kerangka Berpikir. Refika. Bandung.

Tobing, G.H.S, Lumban, 1983, Peraturan Jabatan Notaris, Erlangga, Jakarta

\section{B. PERATURAN PERUNDANG-UNDANGAN}

Kitab Undang Undang Hukum Perdata (KUHPer)

Kitab Undang-Undang Hukum Pidana (KUHP)

Kitab Undang-Undang Hukum Acara Pidana (KUHAP)

Undang-Undang Republik Indonesia Nomor 2 Tahun 2014 Tentang Perubahan Atas Undang-Undang Nomor 30 Tahun 2004 Tentang Jabatan Notaris 